\title{
Time Management Strategies for Improving Librarians' Productivity
}

\author{
Kütüphanecilerin Verimliliklerini Geliştirmek için Zaman \\ Yönetimi Stratejileri
}

\author{
Goodluck Israel IFIJEH*
}

\begin{abstract}
The global financial crisis has affected all aspects of human endeavor; the library is no exemption. Consequently libraries of all types are experiencing budget and staff cuts. Fewer librarians are required to carry out more tasks. Librarians therefore, need to develop survival strategies that will enable them meet their organizational objectives. This paper focuses on time management strategies to improving librarians' productivity, in a bid to beat budget and staff cuts. It examines the effects of budget and staff cuts on libraries, highlights the relationship between time management and productivity and importance of time management to librarians. It also discusses the concept of multitasking. The paper posits that good time management practice among librarians is a sure survival strategy in coping with staff and budget cuts.
\end{abstract}

Keywords: Time management, Librarians, Productivity, Libraries

\section{Öz}

Küresel kriz, insan çabası gerektiren bütün çalışmaları ve istisnasız olarak kütüphaneleri de etkilemiştir. Sonuç olarak bütün kütüphane türlerinde personel ve bütçe kesintileri ortaya çıkmıştır. Bu durum da az sayıdaki kütüphanecinin günlük iş hayatlarında daha çok görevi gerçekleştirmelerini gerektirmiştir. Bu yüzden kütüphanecilerin kurumsal hedefleri yerine getirebilmeleri için yaşamsal stratjiler geliştirmelerine yönelik ihtiyaçlar oluşmuştur. Bu çalışma, bütçe ve personel kesintilerini ortadan kaldırmaya bir alternatif olarak; kütüphanecilerin verimliliklerini geliştirmek için zaman yönetimi stratejileri üzerine odaklanmaktadır. Çalışmada bütçe ve personel kesintilerinin kütüphanelere olan etkisi değerlendirilmekte; zaman yönetimi ile verimlilik ve kütüphaneciler açısından zaman yönetiminin önemi arasındaki ilişki çok görevlilik kavramı bağlamında vurgulanmaktadır. Çalışmanın sonuç bölümünde, kütüphaneciler için iyi zaman yönetimi uygulamalarının bütçe ve personel kesintilerine alternatiföneme sahip stratejiler olduğu belirtilmektedir.

Anahtar sözcükler: Zaman yönetimi, Kütüphaneciler, Verimlilik, Kütüphaneler

* Serials Librarian, Centre for Learning Resources, Covenant University, Ota, Nigeria. (ifijehgoodluck@yahoo.com) 


\section{Introduction}

Libraries and their parent institutions worldwide are currently going through tough times. Institutions' ability to properly fund libraries is under pressure. In the United States of America and indeed other parts of the world, decreases in state tax revenues result in state budget deficits that continue to rise sharply, which puts downward pressure on education and consequently library appropriations. Competition for grants from independent or government funding bodies is fierce. Many libraries are going out of business.

The resultant effects of these challenges are library budget and staff cuts. According to a study conducted by the Association of Governing Boards of Universities and Colleges, among responding public institutions in the United States of America: $79 \%$ experienced budget cuts of $5 \%$ or more in the first quarter of $2009,68 \%$ had further midyear cuts, and $74 \%$ face additional budget cuts for first quarter of 2010 (Toutsi \& Novak, 2009). Most university libraries have experienced a decrease in their share of their institution's budget. From 1998 to 2007, the library expenditure as a proportion of institutional expenditure has declined from $3.0 \%$ to $2.2 \%$. The average library expenditure as a percentage of the average institutional R\&D expenditure has also dropped from 2000 to 2007 from $12 \%$ to $10 \%$ (Toutsi \& Novak, 2009). There maybe speculations about the reasons for losing budget share, but the result is a decline on a relative basis of funding for libraries within research institutions. In the face of reduced budget allocation, staff cuts become inevitable. This implies that there is moderate or drastic reduction in the number of library staff while there is zero level for employment of new staff.

Libraries are service-oriented organizations, whose major objectives are channeled towards meeting the information needs of their users. Therefore, a cut in budget and staff would place a limit on the extent to which any given library would be able to provide and create access to information and ultimately meet the information needs of its users. Budget and staff cuts reduce the libraries' and librarians' productivity. Productivity here means the amount of output per unit of input (labor, equipment, and capital). When there is a reduction in input factor - labor (staff), equipment and capital (funding), productivity also declines. A decline in productivity has consequential effects on library services; the founding philosophy of librarianship - 'the right material, for the right user, at the right time' is defeated. Library patronage by users also experiences decline especially with the internet providing alternative means of information sourcing to the users. It, therefore, means that for libraries and librarians to survive, they must evolve ways to sustain their services to users in the face of budget and staff cuts. This paper focuses on the use of time management strategies to improve librarians' productivity in the face of budget and staff cuts. 


\section{Time Management and Productivity: What Role?}

Wikipedia (2012) defines time management as 'the act or process of planning and exercising conscious control over the amount of time spent on specific activities, especially to increase effectiveness, efficiency or productivity'. This definition establishes a relationship between time and productivity. Effective use of time could increase productivity. Pavlina (2005) defines productivity mathematically as value divided by time (value/time). Libraries create value through the services they render to users. Apparently, one can compare productivity in terms of services rendered as output per time (maybe per hour or day). Librarians carry out different services ranging from collection development and related activities, to technical services, circulation and reference services. To meet target and achieve maximum productivity, they (Librarians) must consciously plan and exercise control over the amount of time to be spent on predetermined activities related to the service(s) they want to render. Maximum productivity is not achieved when output is low in comparison with the amount of time spent.

\section{Importance of Time Management to Librarians}

In the context of staff cuts, one librarian may be required to do the job of three or more persons, most times within the time limit of about eight working hours ( $8 \mathrm{am}-4 \mathrm{pm})$. He or she must be able to manage time if set objectives must be achieved. According to Thompson (2008), time is a very important thing for people all over the world. It is time, which runs this world. Thompson (2008) asserts that 'if we closely introspect ourselves then we would realize that it is time that runs us and not we who control time'. This is particularly true for professionals, including librarians, who normally have limited time within which assigned tasks must be carried out. One major trait of time lies in the fact that it is a non-renewable resource; once time is spent, it cannot be taken back. Sasson (2008) outlined the following as reasons why time management is very important:

$\diamond \quad$ Time is a special resource that one cannot store or save for later use. Time not well used cannot be retrieved.

$\diamond \quad$ Time management can help librarians find the time for what they desire to do or need to do.

$\checkmark \quad$ Librarians need time to get what they want out of life. If they wait for extra time to appear, they might lose the game of life. Through right time management, librarians can "create" the time they need, and not just wait for it to come. By planning their time wisely, they will have more time to do more things.

$\diamond$ Time management will help librarians set up their priorities.

$\diamond \quad$ Time management helps librarians make conscious choices, so they can spend more of their time doing things that are important and valuable to them. 
$\checkmark$ Librarians become more productive using improved time management skills and tools, and can accomplish more with less effort and time. Time management can help them to reduce wasted time and energy, help them to become more creative and productive, and enable them to do the right thing at the right time. This will of course lead to more balance and fulfillment in their lives.

$\diamond \quad$ Time management helps to eradicate or minimize distractions, and therefore, keep the librarian away from spending time on unimportant activities.

$\checkmark$ Time management helps the librarian to focus on important activities and consequently create inner peace and calmness. When you stay calm in spite of distractions or difficulties, you can save a lot of time and energy, which you can spend on better and more rewarding activities.

In summary, time management can help librarians reach the top of their field. According to Tracy (2012), excellent time management is the common denominator of success. In his study of success and successful people, Tracy found that the common denominator of successful people was how they valued their time. They placed a really high value on their time. Time management is critical because time challenges increase frustration and decrease job satisfaction (Peterson, 1997). Peterson further posits that choosing appropriate time management strategies can enhance your life - increase work productivity, bolster self-esteem, and create more time for personal pursuits.

\section{Time Management Strategies}

The concept of time as used in our context connotes measured time. This implies time measured by chronometric devices such as clocks and calendars. We shall therefore, define time as duration measurable in seconds, minutes, hours and days available at our disposal. The term time management means different things to different people. In the most generic sense, it refers to types of behavior that differentiate people who do things 'on time', stick to deadlines and spend little time on their activities from those who are often late, pass deadlines, spend much time on their activities and waste time on unimportant matters. Traditionally, time management refers to the use of particular techniques such as making 'to-do'lists or deliberately planning activities or participation in training with the purpose of learning how to master and use such techniques (Claessens, Roe \& Rutte, 2009).Time management is the set of skills and techniques used to manage time used to complete tasks and goals. It includes activities such as planning, delegation, scheduling, and prioritizing. Time management can include work time only, or both personal and work activities. Attitudes toward time are complex and may vary from person to person. Librarians are bombarded with competing demands on their time. These demands can prove to be overwhelming. 
The ability to identify and focus their attention on the most important tasks may be the difference between a successful and unsuccessful librarian. To manage time well, one must learn how to effectively:

$\diamond$ Analyze the job and identify what to focus time on to achieve personal and organizational goals,

$\diamond \quad$ Develop an ideal picture of how to allocate time between various activities.

$\checkmark$ Develop weekly and daily schedules so that time is focused on activities needed to achieve goals,

$\diamond$ Deal with time challenges such as interruptions, phone calls, emails, and unproductive meetings.

\section{Job Analysis and Goal Setting}

Analyzing your job, involves determining your personal and organizational goals and identifying the roles you are expected to play to achieve them. This may require you itemizing your already determined goals in a scale of priority. Organizational goals require strictly followed daily schedules to achieve them. A practicing librarian may need to design a daily to-do list and allocate time for each of the items on the list. Your to-do list should be realistic, taking into consideration job descriptions whose attainments are important to your organization; do not over crowd the list especially with items you may not be able to attend to within your working hours. Having itemized your job schedule on your to-do list, you then allocate time to each of the item on the list. It is advisable to also allocate time to emergencies, breaks (tea and maybe lunch break), meetings and personal goals. Librarians whose job schedules revolve around customer services like reference, serials and others may need to be disciplined on how much time they give to users who may come for one enquiry or the other. Do not make commitments that you know you cannot meet. If there are time conflicts, talk to the persons involved. While organizational goals are not necessarily determined by the librarians (but the management of their organizations), personal goals are set by them. Personal goal setting involves creating specific, measurable, realistic and time targeted objectives for oneself. Your career progression as a librarian may be dependent on how much of personal goals you able to set for yourself. This discourse therefore, implies that the librarian has the enormous task of efficiently managing time for both organizational and personal goals. For the avoidance of doubt, personal goals may also include family, religious and social responsibilities. They maybe short or long term. However, priority must be given to the achievement of organizational goals especially during official working hours. Staying back at the office after closing hours, may help to create time to attend to some career matters. For example, an academic librarian may decide to use a few hours after work to attend to research or other career matters. You may not need to stay back at work every day of the week; staying back twice or thrice a week may not be a bad idea. One must admit that coping with such schedule is very tedious, be it as it may, it is a sacrifice we must pay if our libraries must cope with budget and consequently staff cuts. Some persons may prefer to spend a few hours at night to make efforts at achieving goals; it is a good idea, however, we must create time for rest, in order to refresh. 


\section{Time Allocation Skills}

Apart from developing daily and weekly schedules so that time is focused on activities needed to achieve goals, there is the need to develop skills to be able to allocate time between various activities. As a first step towards developing skills for proper time allocation to our schedules, we may have to carry out a time audit. A time audit entails taking a critical and retrospective look at the demands on you as a person, your use of time to meet the demands and identifying gaps and possible areas of adjustment. Be prepared to make adjustments in your habits. For example, if your time audit reveals that you spend time unnecessarily in discussions with people you did not schedule to meet, you may need to change that habit and become assertive enough to say 'no' to nonbeneficial and unscheduled discussions. Another important skill in time management is the ability to prioritize and plan ahead. There are times one is forced to make choices in a workplace because of the number job activities requiring attention almost at the same time. At such times, prioritization becomes very important. Prioritization here involves allotting time to each job activity according to its importance to the achievement of set goals. In a situation where two or more job activities are requiring your attention at the same time, there may be need for delegation.

\section{Delegating Tasks}

The role of delegation in time management cannot be overemphasized. Delegation means all that is involved in the process of authorizing a person to act for another. It means entrusting someone to do parts of your job. In an office place like the library, delegation could be defined as sub-allocation of responsibilities with corresponding powers to subordinates in order to achieve effective results. One of the weaknesses of delegation is the fact that it can only flow officially from superiors to subordinates. However, librarians who cultivate good working relationships with their colleagues could make appeals for help when the need arises. Delegation will help you to manage your time well and give you freedom to focus on your priorities (Rooney, 2004). Delegation should not be mistaken for indolence - giving your tasks to others while you do nothing. Ability to delegate tasks appropriately holds a lot of benefits both for the individual and the corporate organization. Delegation will not only provide more time for you to focus on your priority, it will also help you achieve personal effectiveness as you concentrate on the things you do best. It helps the library to develop staff - creates an avenue to test the abilities of staff and increase their contributions to the achievement of the library's objectives. Proper and productive delegation involves correct determination of when to delegate, what to delegate and who to delegate. Note that whatever the outcome of the task (s) you are delegating, you will be held accountable. 


\section{Planning}

To plan is to be proactive. Planning is the act of setting goals and developing appropriate strategies to achieve the set goals. It involves outlining details of set goals, developing strategies and fixing time limits for the achievement of the goals; time limit such as the date by which you will accomplish the goal. By having a plan and setting time limits, you are increasing the likelihood of achieving your goal. One of the most favorite planning tools is the 'to-do list'. Your to-do list should be for a specific and defined period - maybe daily or longer term. What is important is that the list is strictly followed and each task is carried out at the exact time allotted to it.

\section{Identifying and Dealing with Time Wasters}

In order to make maximal use of our time, we need to identify and deal with time wasters. Some of them are discussed here - this list is by no means exhaustive:

\section{Procrastination}

Procrastination implies putting off a task you ought to do now, because you think it can be done later. Most times doing the task 'later' puts you under pressure and stress as you may have to combine the execution of the task with other pressing matters. If you put off that task, it will still be hanging over your head. Procrastination sacrifices efficiency, as more often than not, such postponed tasks are finally carried out at the last minute. Tasks carried out at the last minute are often not properly done; tasks not properly done may have to be repeated, thus wasting your limited time. The solution to procrastination is to practice the 'do it now' approach. This will help to carry out tasks in a timely manner and most especially reduce stress and pressure.

\section{Meetings}

Meetings are compulsory routines in any workplace. Though they are necessary, but if not well handled, they could prove a serious challenge to good time management. Meetings that were originally scheduled for an hour could take two or more hours, thus wasting some of the time already scheduled for other tasks. In order to curb this trend, the following steps are important: decide if you really need a meeting before you call one; if there is need for a meeting, the agenda must be clearly stated and circulated before the meeting; discussions at the meeting must be strictly on the stated agenda; pressing issues should be treated first before other matters; and when a meeting appears to want to over stretch the allotted time, it may be adjourned.

\section{Mails}

Mails especially e-mails could be a source of distraction. An e-mail alert could make you lose concentration on a task you are trying to finish; your curiosity will not let you ignore the alert. To avoid distractions, fix a time interval for checking your mails. You 
may decide to make replies to only mails that are official in nature during office hours while other mails would receive your attention after work. You may also choose to make your replies as brief as possible to reduce time spent on mails.

\section{Telephone Calls}

Telephone calls if not monitored could prove to be a time waster. Unimportant calls during work hours should be politely rejected. Put phone on silence when you need to meet deadlines and probably attend to missed calls when you are less busy.

\section{Unorganized Desk and Work Area}

A person with a messy desk may spend precious time looking for one thing or the other. Looking for misplaced things could be very frustrating. It is better to create a filing system that would enhance retrieval of whatever document one needs within the shortest time possible.

\section{Being Too Simple}

'Being too simple' implies being the nice guy who would never say 'no' to requests. You must learn to turn down low-priority requests that could prevent you from meeting your targets or deadlines.

\section{The Concept of Multitasking}

It makes sense to do one thing at a time and focus all your attention on that one task until you are finished. Some have argued that doing one thing at a time is the most efficient way to spend time. While this assumption may not be far from the fact, the reality in workplaces show that there are times when one is saddled with the responsibility of handling different tasks almost at the same time. A typical example is that of a university library where a librarian may serve on university wide committees; He or she will have to handle responsibilities from such committees alongside tasks in the library. From my personal experience, responsibilities from standing committees could compete for time with your regular tasks as a librarian. Before you know it, you are doing many things at once - which is the whole concept of multitasking. Yager (2008) defines multitasking as combining two tasks at the same time, either at once or by going back and forth between the two. According to Yager, 'it is a conscious decision to tackle these two responsibilities at once'. Multitasking should not be confused with doing too much at once. What differentiates multitasking from doing too much at once is that when you multitask, you are managing all the tasks well, no matter the number of tasks. However, care must be taken to ensure that the workload is manageable. Multitasking implies that all the tasks you are handling are priority concerns. As Yager (2008) puts it, 'if it is not a priority, you should be saying no to a task'. The concept of multitasking demands flexibility. Knowing when to stop what you are doing and switching over to something else is a skill that must be imbibed. 


\section{Conclusion}

Librarians are becoming busier with increasing workloads especially in the face of budget and staff cuts. The only way to handle these workloads is to develop skills to manage time well. This is what this paper has attempted to do. One can only hope that readers would find suggestions provided here useful. I will also add that there a number of commercially available time management toolkits that can help you order your day; but they are only as useful as time invested in using them.

\section{References}

Claessens, B., Roe, R. \& Rutte, C. (2009). Time management: Logic, effectiveness and challenges. In Time in Organizational Research. (p. 23 -41). New York: Routledge.

Toutsi, C. \& Novak, R. (2009). Public institutions and university system financial condition study, Association of Governing Boards of Universities and Colleges, April2009, Retrieved on May 29, 2012 from http://www.uillinois.edu/our/news/budget/Apr20.Apr26.pdf

Rooney, K. (Ed.)(2004). Manage your time: How to work more effectively. New York: Bloomsbury Publishing Plc.

Pavlina, S. (2005). What is productivity. Retrieved on May 28, 2012 from http://www.stevepavlina. com/blog/2005/10/what-is-productivity

Peterson, L.C. (1997).Time management for library professionals. Katharine Sharp Review, 5, Retrieved June 4, 2012 from http://mirrored.ukoln.ac.uk/lis-journals/review/review/5/ peterson.html

Sasson, R. (2012). Importance of Time Management. Retrieved June 4, 2012, from http://www. successconsciousness.com/blog/time-management/importance-of-time-management/

Thompson, J. (2012). Role of time management. Retrieved May 11, 2012 from http://www. articlealley.com

Tracy, B. (2012). Managing your time. Retrieved on May 28 ${ }^{\text {th }}$, 2012 http://www.woopidoo.com/ articles/tracy1time.htm

Wikipedia. (2012). Time Management. Retrieved June, 2012 from http://www.en.wikipedia.org/ wiki/Time

Yager, J. (2008). Workless, do More. NewYork: Sterling. 